\title{
Chemical constituents and pharmacological effects of Dalbergia sissoo - A review
}

\author{
Prof Dr Ali Esmail Al-Snafi \\ Department of Pharmacology, College of Medicine, Thi qar University, Iraq.
}

\begin{abstract}
Previous studies showed that Dalbergia sissoo exerted antimicrobial, neural, cardiac, antioxidant, antiparasitic,antidiabetic,anti-inflammatory,analgesic, Osteogenic, dermatological, gastrointestinal, reproductive and many other effects. The current review highlights the chemical constituents and pharmacological effects of Dalbergia sissoo.
\end{abstract}

Keywords:- chemical constituents, pharmacological effects, Dalbergia sissoo

\section{I-INTRODUCTION:}

Plants are a valuable source of a wide range of secondary metabolites, which are used as pharmaceuticals, agrochemicals, flavours, fragrances, colours, biopesticides and food additives. Two thirds of the new chemicals identified yearly were extracted from higher plants. In the US, where chemical synthesis dominates the pharmaceutical industry, $25 \%$ of the pharmaceuticals are based on plant-derived chemicals Many previous reviews showed that medicinal plants possessed a wide range of pharmacological effects [1-50]. Previous studies showed that Dalbergia sissoo exerted antimicrobial, neural, cardiac, antioxidant, antiparasitic, antidiabetic, anti-inflammatory, analgesic, Osteogenic, dermatological, gastrointestinal, reproductive and many other effects. This review will highlight the chemical constituents and pharmacological effects of Dalbergia sissoo.

Synonyms: Amerimnon sissoo (Roxb.) Kuntze [51].

Taxonomic classification:

Kingdom: Plantae; Phylum: Tracheophyta; Division: Magnoliophyta; Class: Magnoliopsida; Order: Fabales; Family: Fabaceae; Sub Family: Faboideae; Genus: Dalbergia; Species: Dalbergia sissoo [52-53].

\section{Common names:}

Arabic: Sasam, Sarsoa; English: Indian Rosewood, Bombay Blackwood; French: Ebenier Juane; Hindi: Shisham, sissu; Indonesia: du Khaek, Pradu Khack; Persian: Jag; Sanskrit: Shinshapa, Aguru; Spanish: Sisu [54-55].

\section{Description:}

Dalbergia sissoo is a medium to large tree of about 25 meters high with grey yellow trunk, 2-3 meters in diameter. Leaves are leathery, pinnately compound, leaflets are alternate. They are broad, ovate, acuminate, glabrescent, petiolate with fine pointed tip. Flowers are whitish to pink, fragrant nearly sessile, they are 5-8 mm long racemes $2.5-3.7 \mathrm{~cm}$ long in short axillary panicles. It's crown is oval in shape. Pods are oblong, flat, thin, strap like 4-8 cm long and $1 \mathrm{~cm}$ in wide with 1-4 seeds. Seeds are 4-5 mm kidney shaped, thin and flat, light brown. They have long taproot and numerous surface roots which produce suckers. The sapwood is white to pale brown to dark brown in color $[54,56]$.

\section{Distribution:}

Dalbergia sissoo is found in tropical to subtropical climates in natural and planted forests, it was distributed in Pakistan, India, Afghanistan, Bangladesh, Persia, Iraq, Palestine, India, Malaysia, Thailand, Indonesia, Cyprus, Cameroon, Ethiopia, Mauritius, Nigeria, Sudan, Zimbabwe, Kenya, Tanzania and United States of America $[51,55,57]$.

\section{Traditional uses:}

Dalbergia sissoo is broadly used in folk medicine for several diseases. The concentrated extract of heartwood in milk was prescribed in fevers, bark extract was used as anti-inflammatory in piles, sciatica, and as blood purifier. The oil was used externally in the skin diseases and infected ulcers. The wood was used as anthelmintic, antileprotic and cooling. Arial parts were used as spasmolytic, aphrodisiac and expectorant. 
Leaves extract was used as anti diabetic, antioxidant anticancer, analgesic, antipyretic and for jaundice. Flowers were used for Skin problems, as blood purifier and immunity Booster [58-61].

\section{Phyisco-chemical characteristics:}

The extractive values of Dalbergia sissoo leaf were: chloroform extract $4.88 \pm 0.04 \%$, ether extract $9.82 \pm$ $0.02 \%$, hexane extract $7.81 \pm 0.91 \%$, petroleum extract $8.86 \pm 0.48 \%$, ethanol extract $22.78 \pm 0.81 \%, 70 \%$ ethanol extract $28.74 \pm 0.71 \%$, methanol extract $21.47 \pm 0.01 \%$ and aqueous extract $18.94 \pm 0.74 \%$. Total ash $8.43-12.00 \%$, acid insoluble ash $3.33 \pm 0.97 \%$, water soluble ash $4.2 \pm 0.90 \%$ and water insoluble ash 7.8 $\pm 0.91[61-62]$.

\section{II-CHEMICAL CONSTITUENTS:}

The dry weight of leaves of Dalbergia sissoo contained crude protein $18.4-24.1 \%$, fat $3.5-4.9 \%$, nitrogen -free extract $48.5 \%$, crude fiber 0-19.3-26.1\%, ash 8.43-12.0\%, calcium $1855.0 \mathrm{mg} / 100 \mathrm{~g}$ and phosphorus 270.0 $\mathrm{mg} / 100 \mathrm{~g}$ [55,62-63]. Phytochemical investigation of the ethanolic extract of Dalbergia sissoo indicated the presence of carbohydrates, proteins, amino acids, phenolic compounds, flavanoids, alkaloids, saponin, phytosterols, steroids and tannins [64-68].The compounds isolated from the ethyl acetate fraction of Dalbergia sissoo and their percent were: R-(2,2,3,3-2H4) Butyrolactone 3.58; Formic acid,1-methylethyl ester 7.38; Propene 3,3,3-D3 4.22; 2-Propanamine 3.03; 2-Amino-1-propanol 1.71; Pentanal 2.29; Guanosine 2.02; Acetaldehyde 1.47; Cyclobutanol 0.47; 3-Amino-2-ethylbutanoic acid 2.63; 2-Oxo-Butanoic acid 1.49; Benzenemethanol, 2-2-aminopropoxy 7.29; 2-Fluoro-betahydroxy benzeneethanamine 1.00; L-Alanine, methyl ester 1.49; 3-Hydroxycarbonyl-2,5- diethylpyrrolidine 7.83; 1, 2- Benzenedicarboxylic acid dibutyl ester 13.68; 2, 2- Dimethyl-4-methylaminobutanone 5.27; 5-Nirto,2,4-Pyrimidinedione 7.94; 2-Isocyanato-Propane 6.56 and Oxirane 1.98 [69].A chalcone [ $(E)-3$ - (3,4-dihydroxyphenyl)-1-(2,3,4-trihydroxyphenyl) prop-2-en-1-one] or okanin was isolated from te leaves of Dalbergia sisso [70].Three water-soluble polysaccharides were isolated and purified from the leaves of Dalbergia sissoo[71].The repeating unit of Dalbergia sissoo polysaccharide was found to be composed of $\alpha$-L-rhamnose, $\beta$-D-glucuronic acid, $\beta$-D-galactose and $\beta$ D-glucose in the molar ratio of 1.00:1.00:2.00:2.33, respectively. The structure of polysaccharide was mainly composed of $(1 \rightarrow 2),(1 \rightarrow 3),(1 \rightarrow 4)$ linkages [72]. However, Dalbergia sissoo leaves yielded $14.0 \%$ pure polysaccharide, containing $15.7 \%$ of glucuronic acid. Complete hydrolysis and GLC analysis of alditol acetate derivatives of reduced and unreduced monosugars indicated the presence of L-rhamnose, D-glucuronic acid, Dgalactose and D-glucose in 1.00:1.00:2.00:2.33 molar ratios [73].Seed oil (4.1\%) contained fatty acids composed of palmitic $(16.2 \%)$, stearic $(7.0 \%)$, oleic $(14.6 \%)$, linolenic $(9.8 \%)$ and linoleic $(52.5 \%)$ acids and lipids comprising neutral lipids (88.5), glycolipids (7.2) and phospholipids (4\%). Pods contain $2 \%$ tannins [68]. Two isoflavone glycosides: sissotrin, biochanin A 7-O-[beta-D-apiofuranosyl-(1-->5)-beta-D-apiofuranosyl$(1 \rightarrow 6)$-beta-D-glucopyranoside] and tectorigenin 7-O-[beta-D-apiofuranosyl-( $1 \rightarrow 6)$-beta-D-glucopyranoside], were isolated from Dalbergia sissoo [68,74]. Isoflavone glucoside, caviunin 7-O-[ $\beta$-d-apiofuranosyl- $(1 \rightarrow 6)-\beta$ d-glucopyranoside] and a new itaconic derivative, (E)-4-methoxy-2-(3,4-dihydroxybenzylidene)-4-oxobutanoic acid along with series of isoflavones and flavonols with their glucosides and a lignan glucoside were isolated from the ethanolic extract of Dalbergia sissoo leaves [75]. The stem-bark of Dalbergia sissoo has yielded, besides the known compounds dalbergenone, dalbergin and methyl dalbergin, a new 4-phenyl chromene, dalbergichromene. Its structure has been determined as 7-methoxy-6-hydroxy-4-phenyl chrom-3-ene [76].

Two isoflavone glycosides caviunin 7-O-gentiobioside and isocaviunin 7-O-gentiobioside has been isolated from the mature pods of Dalbergia sissoo [77].Dalbergenone, methyldalbergin, dalbergichromene were also known constituent of bark of Dalbergia sissoo. Irisolidone, biochenin-A, muningin, tectirigenin, prunetin, genistein, sissotrin, prunetin-4-O-galactoside, norartocarpetin, $\beta$-amyrin, $\beta$-sitosterol, and stigmasterol along with 13 fatty acids were isolated from the green branches of aerial parts of Dalbergia sissoo [78].

Total phenolic contents of the various extracts of Dalbergia sissoo were estimated as $50.8 \mathrm{mg} / \mathrm{g}$ [79].

However, Kumari and Kakkar found that the total phenolic was 58.06 gallic acid equivalents (GAE) mg/g of extract and tannin content was varied from 218.34 to $61.75 \mathrm{mg}$ catechin equivalent (CE)/g of extract [80].

\section{III-PHARMACOLOGICAL EFFECTS:}

\section{Antiparasitic effect:}

The petroleum ether, carbon tetrachloride, benzene and ethanol extracts of leaves of Dalbergia sissoo were assessed for anthelmintic activity against Indian earthworms (Pheretima posthuma) at different concentrations of $(10,25,50$, and $100 \mathrm{mg} / \mathrm{ml})$, and compared wth piperazine citrate. All the extracts revealed anthelmintic activity against the eartworms, carbon tetrachloride extract exhibited the most ptent activity with the paralysis time of $19.14 \pm 2.78 \mathrm{~min}$ and death time of $48.15 \pm 3.23 \mathrm{~min}$ at the concentration of $100 \mathrm{mg} / \mathrm{ml}$, while piperazine citrate showed paralysis time and death time of $5.23 \pm 0.72$ and $20.45 \pm 2.33 \mathrm{~min}$, respectively at the concentration of $10 \mathrm{mg} / \mathrm{ml}[81]$. 
The anthelminthic activity of ethanolic extract of bark of Dalbergia sissoo was investigated against Indian earthworms Pheretima posthuma and nematode Ascardi galli. The extract was tested in various concentrations $(10,20,50 \mathrm{mg} / \mathrm{ml})$ and compared with piperazine citrate $(15 \mathrm{mg} / \mathrm{ml})$ and albendazole $(20 \mathrm{mg} / \mathrm{ml})$ as standard reference and normal saline as control. The result showed that the extract of Dalbergia sissoo possessed strong anthelminthic activity [82].Adult immersion test was employed to study the acaricidal activity of leaf extracts of Dalbergia sissoo against resistant ticks. Mortality and fecundity of ticks exposed to leaf aqueous (SLA) and ethanolic (SLE) extracts were evaluated at concentrations of $0.625,1.25,2.5,5.0$ and $10.0 \%$ and controls (distilled water and $10 \%$ ethanol). Higher acaricidal activity was recorded in SLA with a lower $\mathrm{LC}_{50}$ (95\% CL) value of $1.58 \%(0.92-2.71 \%)$ than SLE [5.25\% (4.91-5.63\%)]. A significant decrease in egg mass weight and reproductive index was recorded in treated ticks along with an increase in percent inhibition of oviposition. A complete inhibition of hatching was recorded in eggs laid by ticks treated with higher concentrations of SLA, whereas, SLE exhibited no effect on hatching percentage [83].The molluscicidal effects of the crude aqueous and ethanolic extracts of Dalbergia sissoo fruits, leaves, roots and stem bark were studied against egg masses of Biomphalaria pfeifferi, the snail intermediate host of Schistosoma mansoni in Nigeria. Viable 0-24 hr-old embryonated egg masses were separately exposed to five different concentrations (7.81$2000 \mathrm{mg} / \mathrm{l}$ ) of extracts for $24 \mathrm{hrs}$, washed in dechlorinated tap water and incubated at room temperature for a maximum of 4 weeks. The $\mathrm{LC}_{50}$ and $\mathrm{LC}_{90}$ values of the tested extracts for egg masses were calculated by probit analysis. The activities of the tested extracts were concentration-dependent. However, only the ethanolic extract of the fruits demonstrated significant activity $\left(24 \mathrm{hr}-\mathrm{LC}_{90}\right.$ value $\left.<100 \mathrm{mg} / \mathrm{l}: 89.29 \mathrm{mg} / \mathrm{l}\right)$. Mortalities of eggs were manifested at the gastrula/exogastrula and or the prehatch snail stage of development. The percentage of dead embryos at the prehatch snail stage decreased while the deaths of embryos at the gastrula/exogastrula stage increased, with increasing concentration of extract [84]. The larvicidal, growth inhibitor and repellent actions of Dalbergia sissoo oil was studied against Anopheles stephensi, Aedes aegypri and Culex quinquefasciacus. Pure oil was applied at $0.4-5 \mathrm{ml} / \mathrm{m}^{2}$ on a water surface. This showed larvicidal activity directly proportional to dosages. One hundred percent mortality of immature Culex quinquefasciacus was observed within 24 hrs at $4 \mathrm{ml} / \mathrm{m}^{2}$, followed by Anopheles stephensi $(60 \%)$, and pupation was totally inhibited. The oil also showed strong repellent action when $1 \mathrm{ml}$ oil was applied on exposed parts of human volunteers. They were protected from mosquito bites for $8-11 \mathrm{~h}$. The protection $(91.6 \pm 2 \%)$ was recorded with Dalbergia sissoo oil as compared to that with commercial available Mylol oil (93 $1.2 \%)$ consisiting of di-butyl and dimethyl phthalates [85].

\section{Antiinflammatory and analgesic effects:}

The anti-inflammatory activity of hexane and methanol extracts of Dalbergia sisso and okanin was evaluated by carrageenan induced paw oedema in rats. The methanolic extract showed maximum activity [70]. The antiinflammatory activity of a $90 \%$ ethanolic extract of Dalbergia sissoo bark was studied using a right hind paw oedema method in Wistar rats. After oral administration of ethanolic extract at different doses $(300,500$ and $1000 \mathrm{mg} / \mathrm{kg}$ ), inhibition of right hind paw oedema was observed at 30, 60, and 120 min time intervals. The antiinflammatory effects increased with increasing doses. The ethanolic extract of Dalbergia sissoo bark at $1000 \mathrm{mg} / \mathrm{kg}$ showed the most potent anti-inflammatory activity compared to the other doses (300 and 500 $\mathrm{mg} / \mathrm{kg}$ ) throughout the observation period [64].The analgesic and anti-inflammatory properties of the methanolic extract of leaves of Dalbergia sissoo were evaluated by using acetic acid induced writhing and hot plate tests in mice and carrageenan- induced paw oedema in rats. Oral pretreatment with the leaves extracts of Dalbergia sissoo significantly decreased the writhing movements in mice in acetic acid-induced writhing test and significantly increase the mean pain latency time in mice placed on the hot plate at $50^{\circ} \mathrm{C}$ at dose dependant manner. In the carrageenan-induced paw oedema model, the methanolic extract afforded $68.2 \%$ inhibition of hind paw oedema in rats at the highest dose $(600 \mathrm{mg} / \mathrm{kg})$ compared to $73.4 \%$ inhibition obtained with the reference drug, diclofenac $(5 \mathrm{mg} / \mathrm{kg})$ at the third hour after carrageenan administration [86].The alcoholic extract of Dalbergia sissoo seeds was evaluated for analgesic and antipyretic activities. The peripheral analgesic activity of seed extract was studied using acetic acid-induced writhing in mice and by Randall-Selitto assay in rats. Furthermore, the central analgesic activity of seeds extract was studied by tail-clip test and hot plate method in mice. The antipyretic activity of seeds extract was studied in Brewer's yeast-induced pyrexia in rats. The alcoholic extract of Dalbergia sissoo seeds was significantly decreased writhing movements of acetic acid-induced writhing in mice, and significantly increased the pain threshold capacity in rats in Randall-Selitto assay and the reaction time in hot-plate test but not in tail-clip test. Moreover, it also showed significant antipyretic activity in Brewer's yeast-induced pyrexia in rats throughout the observation period of $6 \mathrm{~h}$ [87].

The analgesic activity of the ethanol extract of the bark of Dalbergia sissoo was investigated using the tail flick method in Wistar rats. The extract at the doses of 300, 500 and $1000 \mathrm{mg} / \mathrm{kg}$ possessed significant and dose dependent, central analgesic activity, compared with the standard drug aspirin at the dose of $300 \mathrm{mg} / \mathrm{kg}$. An ethanol extract of the leaves of Dalbergia sissoo showed both peripheral and central analgesic activity in a dose dependent manner. Peripheral analgesic activity was studied using the acetic acid-induced writhing reflex and 
Randall-Selitto assays in mice, while, central analgesic activity was studied using the hot-plate and tail-clip tests in mice. In writhing test, the extract $(100,300$ and $1000 \mathrm{mg} / \mathrm{kg})$ moderately inhibited writhing in mice, in Randall-Selitto assay, the extract failed to increase pain threshold level at the doses of 100 and $300 \mathrm{mg} / \mathrm{kg}$ but exhibited significant $(\mathrm{P}<0.01)$ activity at the dose of $1000 \mathrm{mg} / \mathrm{kg}$, the extract $(1000 \mathrm{mg} / \mathrm{kg})$ increased reaction time at 2 and $3 \mathrm{~h}$ while pathidine $(5 \mathrm{mg} / \mathrm{kg})$ increased reaction time at 1 and $2 \mathrm{~h}$. The ethanol extract of the leaves of Dalbergia sissoo showed significant antipyretic activity in a Brewer's yeast-induced pyrexia assay in rats. The extract at the doses of 100 and $300 \mathrm{mg} / \mathrm{kg}$ showed significant antipyretic activity at $1 \mathrm{~h}$ after drug administration while at the $1000 \mathrm{mg} / \mathrm{kg}$, it showed activity throughout the observation period up to $6 \mathrm{~h}$ and the effect was comparable to aspirin $(300 \mathrm{mg} / \mathrm{kg}$ ) [88-89].The analgesic potential of the ethanolic bark extract of Dalbergia sissoo bark was measured by the Radiant Heat method (tail flick method). The bark extract showed significant analgesic activity as evidenced by the increase in reaction time to the pain stimulus. The extract 300 and $500 \mathrm{mg} / \mathrm{kg}$ failed to alter pain threshold capacity but, it increased significantly at the dose of $1000 \mathrm{mg} / \mathrm{kg}$ at $30 \mathrm{~min}$ [67]. The antinociceptive activity of ethanolic extract of the plant bark of Dalbergia sissoo was investigated using tail flick method on Wistar rats. Three different dose levels $(300,500$, and $1000 \mathrm{mg} / \mathrm{kg}) \mathrm{in}$ $0.5 \%$ carboxyl methyl cellulose were administered orally. At these doses, the extract exhibited significant and dose-dependent antinociceptive activity [66].

\section{Antidiabetic effect:}

The ethanol, ethyl acetate, n-butanol and petroleum ether extracts of the leaves of Dalbergia sissoo were investigated for antidiabetic activity in alloxan induced diabetic rats. The extracts produced a significant antidiabetic effect on first, third, fifth and seventh days at $300 \mathrm{mg} / \mathrm{Kg}$ body weight. Among all the extracts of Dalbergia sissoo, ethanol extract of leaves exhibited highly significant antidiabetic activity which was comparable with the standard drug, Glibenclamide [90]. The hypoglycemic effect of ethanolic extract of Dalbergia sissoo leaves was evaluated in alloxanized diabetic rats. The ethanolic extract of Dalbergia sissoo leaves was administered orally at different doses $(250$ and $500 \mathrm{mg} / \mathrm{kg}$ ) to normal rats. The dose of $500 \mathrm{mg} / \mathrm{kg}$ was found to be more effective in oral route and it decreases blood glucose level (BGL) by $38.2 \%$ in normal healthy rats after 1 day of administration. After daily treatment with the both doses $(250$ and $500 \mathrm{mg} / \mathrm{kg}) \mathrm{of}$ ethanolic Dalbergia sissoo extract for 21 days to severely diabetic (FBG 300-350 mg/dl) rats, the BGL reduced to $125 \mathrm{mg} / \mathrm{dl}$ by $250 \mathrm{mg} / \mathrm{kg}$ and to $104 \mathrm{mg} / \mathrm{dl}$ by $500 \mathrm{mg} / \mathrm{kg}$. It was more effective when compare with the standard drug glibenclamide. It reduced blood glucose level up to $189.2,115.2,104.6 \mathrm{mg} / \mathrm{dl}$ at successive days of $7,14,21$, at the dose of $500 \mathrm{mg} / \mathrm{kg}$ compare with standard drug which reduces blood glucose level up to $250.2,141.2,120.4 \mathrm{mg} / \mathrm{dl}$. In comparison to glibenclamide, the extract was $12 \%$ more effective in reducing blood glucose level [91].The antidiabetic potential of alcoholic and aqueous stem bark extract of Dalbergia sissoo and their fractions was studied on streptozotocin-nicotinamide induced type 2 diabetic rats. The study also included estimations of blood glucose levels, lipid profile, liver glycogen, body weight and antioxidant status in normal and diabetic rats. The results showed that alchohalic extracts $(250$ and $500 \mathrm{mg} / \mathrm{kg}$ ) and aqueous extract $(400 \mathrm{mg} / \mathrm{kg})$ significantly reduced the blood glucose level $(\mathrm{P}<0.05)$, whereas hexane soluble extracts and butane soluble extract did not reduce the blood glucose level significantly. Alcoholic and aqueous extracts significantly restored the lipid profile and showed improvement in liver glycogen, body weight and antioxidant status in diabetic rats [92].

The antidiabetic effect of ethanolic extract of Dalbergia sissoo bark (250 and $500 \mathrm{mg} / \mathrm{kg}$ ) was investigated in alloxan induced diabetic rats. The two doses caused significant reduction in blood glucose levels. The effect was more pronounced in $500 \mathrm{mg} / \mathrm{kg}$ than $250 \mathrm{mg} / \mathrm{kg}$. Dalbergia sissoo also caused significant increase in body weight and glycogen content in liver of alloxan -induced diabetic rats while there was significant reduction in the levels of serum triglyceride and total cholesterol. Dalbergia sissoo also caused significant improvement in the pancreas of alloxan -induced diabetic rats [93].

\section{Dermatological effects:}

The cytotoxicity and in vitro melanogenic activity on bark of Dalbergia sissoo were studied. The various successive bark extracts have been individually evaluated for trials of spontaneous melanin content, and cell viability by the MTT assay in murine B16F10 melanoma cells in vitro. Based on the percentage of cell viability assay, graded concentration of extracts were taken for in vitro melanogenic activity. The result indicated that ethyl acetate extract of bark of Dalbergia sissoo was non-toxic and increased melanin activity as compared to hexane and ethanol extracts. The authors concluded that the bark of Dalbergia sissoo stimulates B16F10 melanogenesis at very low concentrations which support the folk medicinal use of Dalbergia sissoo in the treatment of hypopigmentation diseases, such as vitiligo [94]. 


\section{Osteogenic effects:}

The effect of Dalbergiphenol (DGP), the neoflavonoid isolated from heartwood was evaluated in bone loss in ovariectomized mice. Adult BALB/c mice were ovariectomized and administered DGP (1 and 5 $\mathrm{mg} / \mathrm{kg} / \mathrm{d}$ ) or 17ß-estradiol (E2) orally for 6 weeks. The sham group and the ovariectomy (OVX) + vehicle group served as controls. Uterine estrogenicity, bone microarchitecture, biomechanical strength, new bone formation (based on bone formation rate and mineral apposition rate), and skeletal expression of osteogenic and resorptive gene markers were studied. The sham group and the ovariectomy (OVX) showed marked increase in body weight and a decrease in femoral and vertebral trabecular bone volume that were prevented by DGP or E2 treatment. DGP treatment increased bone biomechanical strength and new bone formation rate in ovariectomized mice, comparable with E2 treatment. However, increase in uterine weight and estrogenicity were observed in E2-treated ovariectomized mice, but not in response to DGP treatment. Treatment with DGP increased messenger RNA expression of runt-related transcription factor 2, osterix, and collagen type I, and decreased messenger RNA expression of tartrate-resistant acid phosphatase and the osteoprotegerin-to-receptor activator of nuclear factor- $\mathrm{KB}$ ligand ratio in the femur of ovariectomized mice. The authors concluded that DGP treatment can effectively prevent OVX-induced increase in bone loss and decrease in bone strength possibly by increasing osteoblastic activities and by decreasing osteoclastic activities [95].

The skeletal effects of an extract made from the leaves and pods of Dalbergia sissoo (butanol-soluble standardized fraction [BSSF]) was studied in ovariectomized rats, a model for postmenopausal osteopenia. In comparison with ovariectomized rats treated with vehicle, BSSF treatment in improved trabecular microarchitecture of the long bones, increased biomechanical strength parameters of the vertebra and femur, decreased bone turnover markers (osteocalcin and type I collagen) and expression of skeletal osteoclastogenic genes, and increased new bone formation and expression of osteogenic genes in the femur. Overall, the osteoprotective effects of BSSF were comparable to those of 17ß-estradiol [96].

The new isoflavone glucoside, caviunin 7-O-[ $\beta$-D-apiofuranosyl- $(1 \rightarrow 6)-\beta$-D-glucopyranoside] and four known compounds namely genstein, biochanin $\mathrm{A}$, pratensein and biochanin 7-O-glucoside, isolated from the leaves of Dalbergia sissoo, showed osteogenic activity in primary calvarial osteoblast cultures. These compounds showed increased alkaline phosphatase activity and mineralization, which substantiated potential osteogenic activity. The compounds at the concentrations ranging from $1 \mathrm{pM}$ to $1 \mu \mathrm{M}$ were applied to calvarial osteoblast cells to screen alkaline phosphatase activity as well as stimulatory activity on osteoblast formation mediated via estrogen receptor (ER). It was found that differentiation of osteoblast formation was ER independent. Caviunin 7- $O$-[ $\beta$-D-apiofuranosyl-( $(1 \rightarrow 6)-\beta$-D-glucopyranoside], genstein, pratensein and biochanin 7-O-glucoside, failed to inhibit ALP production except mild response from biochanin A . Biochanin A inhibited osteoblast formation at the concentration of $10 \mathrm{nM}$ in the presence of ICI-182780 (antiestrogen). All these five compounds also induced the formation of mineralized nodules in osteoblast cultures. Caviunin 7- $O$ [ $\beta$-D-apiofuranosyl-( $(1 \rightarrow 6)-\beta$-D-glucopyranoside] showed most potent osteogenic activity than the other four compounds [75].

The leaves and pods extract of Dalbergia sissoo showed antiresorptive and bone-forming effects. The positive skeletal effect attributed to active molecules present in the extract of Dalbergia sissoo. Caviunin 7-O-[ $\beta$-D-apiofuranosyl-(1-6)- $\beta$-D-glucopyranoside] (CAFG), a novel isoflavonoid found in high percentage in the extract was studied as an alternative for anabolic therapy for the treatment of osteoporosis by stimulating bone morphogenetic protein 2 (BMP2) and Wnt/ $\beta$-catenin mechanism. CAFG supplementation improved trabecular micro-architecture of the long bones, increased biomechanical strength parameters of the vertebra and femur and decreased bone turnover markers better than genistein. Oral administration of CAFG to osteopenic ovariectomized mice increased osteoprogenitor cells in the bone marrow and increased the expression of osteogenic genes in femur and showed new bone formation without uterine hyperplasia. CAFG increased mRNA expression of osteoprotegerin in bone and inhibited osteoclast activation by inhibiting the expression of skeletal osteoclastogenic genes. CAFG was also an effective accelerant for chondrogenesis and has stimulatory effect on the repair of cortical bone after drill-hole injury at the tissue, cell and gene level in mouse femur. At cellular levels, CAFG stimulated osteoblast proliferation, survival and differentiation. Signal transduction inhibitors in osteoblast demonstrated involvement of p-38 mitogen-activated protein kinase pathway stimulated by BMP2 to initiate Wnt/ $\beta$-catenin signaling to reduce phosphorylation of GSK3- $\beta$ and subsequent nuclear accumulation of $\beta$-catenin. Osteogenic effects were abrogated by Dkk1, Wnt-receptor blocker and FH535, inhibitor of TCF-complex by reduction in $\beta$-catenin levels. CAFG modulated MSC responsiveness to BMP2, which promoted osteoblast differentiation via Wnt/ $\beta$-catenin mechanism. CAFG at $1 \mathrm{mg} / \mathrm{kg} /$ day dose in ovariectomy mice (human dose $\sim 0.081 \mathrm{mg} / \mathrm{kg}$ ) led to enhanced bone formation, reduced bone resorption and bone turnover better than well-known phytoestrogen genistein. Accordingly, it could be positioned as a potential drug, food supplement, for postmenopausal osteoporosis and fracture repair [97]. 


\section{Antimicrobial effect:}

The methanol, hexane extracts and isolated okanin from methanol extracts were exhibited good antibacterial activity towards various pathogens, Gram positive (Micrococcus luteus and Staphlcocous aureus) and Gram negative bacteria (Escherichia coli, R. planticola and Acinetobacter) [70].

1,2-benzenedicarboxylic acid dibutyl ester $(13.68 \%)$ and 5-nirto-2,4 $(1 \mathrm{H}, 3 \mathrm{H})$-pyrimidine dione isolated from the plant, showed antibacterial activity against Staph aureus, Bacillus cereus, Serratia marcescens and Proteus mirabilis [69].

A herbal preparation containing Dalbergia sissoo and Datura stramoium was evaluated for its antibacterial potential against pathogenic strains of Gram positive (Staphylococcus aureus and Streptococcus pneumoniae) and Gram negative (Escherichia coli, Pseudomonas aeruginosa and Klebsiella pneumoniae) bacteria. The extracted fractions of the herbal preparation were found active against both Gram positive as well as Gram negative bacteria. Gram positive bacteria showed higher sensitivity [98]. Dalbergia sisso was evaluated for its antibacterial potential against eight human pathogenic bacterial strains. Triple maceration method was adopted for the methanolic extraction of whole plant and leaves. In vitro, antimicrobial test was performed by disc diffusion method. Whole plant's extract showed good antibacterial activity against $S$. aureus $(18.00 \mathrm{~mm})$, S. pneumoniae $(17.50 \mathrm{~mm})$, B. cereus $(17.90 \mathrm{~mm})$, B. pumilus $(16.45 \mathrm{~mm})$, E. coli $(19.00 \mathrm{~mm})$, K. pneumoniae $(17.45 \mathrm{~mm})$, P. aeruginosa $(16.20 \mathrm{~mm})$ and $C$. freundii $(15.00 \mathrm{~mm})$, with relative percentages of inhibition of $81.00,80.54,76.65,64.65,78.45,72.45,70.37$ and 62.30 respectively, as compared with leaves with relative percentages of inhibition of 70.56, 67.32, 54.20, 43.24, 62.80, 57.03, 51.05 and 36.65 against same microbes. Modified agar well diffusion method was used to measure the minimum inhibitory concentration.MIC values of the whole plant extract lies within the range of 75 to $300 \mu \mathrm{g} / \mathrm{ml}$ for the Gram positive strains while 75 to $600 \mu \mathrm{g} / \mathrm{ml}$ for Gram negative strains [99].

\section{Antioxidant effect:}

Extract of bark of Dalbergia sissoo Roxb (Fabaceae) was assessed for its antioxidant activity by in vitro methods. Antioxidant activity was studied using hydrogen peroxide scavenging activity and reducing power assay. The extracts exhibited significant antioxidant activity [100]. The ethanol extract of the bark of Dalbergia sissoo was screened for lipid peroxidation inhibitory (LPO). The bark extract showed $69.1 \%$ LPO inhibitory potential/10 $\mu \mathrm{g}$ of extract [80]. The antioxidant activity of the aqueous and methanol extracts of the stem bark of Dalbergia sissoo was evaluated by 1,1-diphenyl-2-picrylhydrazyl (DPPH) radical scavenging activity, ferric ion reducing power, ferrous ion chelating activity and Au nanoparticle formation potential. In all the assays, aqueous extract showed significantly greater activity than methanol extracts [101].

The in vitro antioxidant activity of the successive petroleum ether, chloroform and methanol extracts of the stem bark of Dalbergia sissoo was investigated through DPPH free radical scavenging activity, reducing power, FRAP (ferric reducing antioxidant power) assay, ferrous ion scavenging activity and nitric oxide (NO) radical scavenging activity. Among different extracts, the chloroform extract was found to be most potent showing the $\mathrm{IC}_{50}$ of $25 \mu \mathrm{g} / \mathrm{ml}$ for DPPH model, $21 \mu \mathrm{g} / \mathrm{ml}$ for reducing power, $26 \mu \mathrm{g} / \mathrm{ml}$ for ferrous ion scavenging, $26 \mu \mathrm{g} / \mathrm{ml}$ for FRAP assay and $25 \mu \mathrm{g} / \mathrm{ml}$ for NO scavenging activity, which were comparable to positive control (ascorbic acid). The activity of petroleum ether and methanol extract was found to be moderate. Total phenolic contents of the various extracts were estimated as $50.8 \mathrm{mg} / \mathrm{g}$. Strong positive correlation was recorded between the antioxidant activity and total phenolic content of the different extracts [79].

Antioxidant activity of methanolic extract of Dalbergia sissoo root was investigated for its free radical scavenging activity by determining the nitric oxide and hydrogen peroxide scavenging activity. Maximum scavenging of nitric oxide and hydrogen peroxide were $26.66 \%$ and $50.68 \%$ respectively at $250 \mu \mathrm{g} / \mathrm{ml}$ concentration. The results were compared with rutin as a standard [102]. Three water-soluble polysaccharides were isolated and purified from the leaves of Dalbergia sissoo. Antioxidant and moisture preserving activities of these three polysaccharides were investigated using in vitro methods. The antioxidant activities studied including testing of superoxide $\mathrm{O}^{2-}, \quad$ 1,1-diphenyl-2-picrylhydrazyl (DPPH), 2,2'-azino-bis(3ethylbenzthiazoline-6-sulfonic acid) (ABTS, hydroxyl $\mathrm{OH}^{-}$, nitric oxide (NO), N,N-dimethyl-pphenylenediamine (DMPD) radical scavenging activities, ferric ion $\mathrm{Fe}^{3+}$ reducing ability, ferrous ion $\left(\mathrm{Fe}^{2+}\right)$ chelating and lipid peroxidation activities. The result revealed water-soluble polysaccharides possessed antioxidant characteristics. Furthermore, the polysaccharides showed effective moisture retention properties in comparison with hyaluronic acid and glycerol [71].

Many constituents, also isolated from other species ( $D$. odorifera) included 4,2',5'-trihydroxy-4'methoxychalcone, (2S)-6,4'- dihydroxy-7-methoxyflavan, 6,4'-dihydroxy-7-methoxyflavanone, $R(+)-4$ methoxydalbergione, $\quad R(-)$-latifolin, $\quad R(+)$-dalbergiphenol, 9-hydroxy-6,7-dimethoxydalbergiquinol and isoparvifuran showed a protective effect on glutamate-induced oxidative injury in HT22 cells. All compounds were tested at the concentrations of $1,10,20$ and $50 \mu \mathrm{M}$ and compared with trolox (positive control). $\mathrm{EC}_{50}$ 
values were of $7.47,2.85,3.3,8.54,5.82,6.54,8.14$ and $3.09 \mu \mathrm{M}$, for these compounds respectively in comparison with trolox which showed EC50 value of $15.8 \mu \mathrm{M}$ [103].

\section{Antiulcer effect:}

The antiulcer effects of Dalbergia sissoo stem bark methanol extract (DSME) was studied against the diclofenac sodium-induced ulceration in rat. The DSME (200 and $400 \mathrm{mg} / \mathrm{kg}$ body weight) was orally administered to rats once a day for 10 days in diclofenac-treated rats. The gastroprotective effects of DSME were determined by assessing gastric-secretory parameters such as volume of gastric juice, $\mathrm{pH}$, free acidity, and total acidity. Biochemical studies of gastric mucosa were conducted to estimate the levels of nonprotein sulfhydryls (NP-SHs), lipid peroxidation [thiobarbituric acid reactive substances (TBARSs)], reduced glutathione $(\mathrm{GSH})$, hydrogen peroxide $\left(\mathrm{H}_{2} \mathrm{O}_{2}\right)$, levels of scavenging antioxidants, catalase (CAT), superoxide dismutase (SOD), glutathione peroxidase (GSH-Px), glutathione-S-transferase (GST), and myeloperoxidase (MPO). Moreover, adherent mucus content and histological studies were performed on stomach tissues. Administration of DSME significantly decreased the ulcer index, TBARSs, $\mathrm{H}_{2} \mathrm{O}_{2}$, and MPO activity in gastric mucosa of the ulcerated rats. Activities of enzymic antioxidants, CAT, SOD, GSH-Px, GST and GSH, and NPSH contents were significantly increased with DSME treatment in diclofenac-treated rats. Volume of gastric juice, total and free acidity were decreased, whereas $\mathrm{pH}$ of the gastric juice was increased with the administration of DSME + diclofenac [104]. The antiulcer activity of crude ethanolic bark extract of Dalbergia sissoo(EBED) was evaluated using pylorus ligation and indomethacin induced ulcer model in Wistar albino rats. The study revealed significant decrease $(\mathrm{P}<0.01)$ in mean ulcer index in EBED treated group in both models compared to control. Furthermore, there were significant decrease $(\mathrm{P}<0.01$ and $\mathrm{P}<0.001)$ in the offensive factors like free and total acidity, pepsin content and protein content, with a significant increase in the defensive factors like total carbohydrate content $(\mathrm{P}<0.01)$ and ratio of total carbohydrates and proteins as compared to control in dose dependent manner [105].

\section{Antidiarrhoeal effect:}

The ether, ethanol, and aqueous extracts of Dalberjia sissoo bark were studied for anti-diarrhoeal properties in experimental diarrhea, induced by castor oil in rats at te dose of $200-400 \mathrm{mg} / \mathrm{kg}$ orally, the ether extract showed significant and dose dependent anti-diarrhoeal activity. The extracts also significantly reduced the intestinal transit time in charcoal meal when compared with atropine sulphate $(1 \mathrm{mg} / \mathrm{kg}$ ip $)$ The ether extract was found to be equipotent to atropine [106-107]. The protective effect of ethanol extract from Dalbergia sissoo leaves (EDSL) was studied in experimentally induced diarrhoea and peristalsis in mice. Castor oil-induced diarrhoea and magnesium sulphate $\left(\mathrm{MgSO}_{4}\right)$-induced diarrhoea tests were used to assess the antidiarrhoeal activity of Dalbergia sissoo. Gastrointestinal tract transit of charcoal meal test and barium sulphate milk was used to assess the peristalsis activity of the extract. The EDSL significantly reduced faecal output in castor oilinduced and $\mathrm{MgSO} 4$-induced diarrhoea and also significantly reduced the number of diarrhoeal episodes. Dalbergia sissoo significantly delayed the onset of diarrhoea induced by both castor oil and $\mathrm{MgSO}_{4} \mathrm{Comparable}$ to loperamide, a standard antidiarrhoeal drug. Both Dalbergia sissoo and atropine sulphate significantly reduced the peristalsis activity of charcoal meal and barium sulphate milk in mice [108].The effect of a decoction of dried leaves of Dalbergia sissoo was evaluated in diarrhea. Antibacterial, antiprotozoal, and antiviral activities of the plant decoction were checked by agar dilution method, tube dilution method, and neutral red uptake assay, respectively. Cholera toxin and Escherichia coli labile toxin (LT) were assayed by ganglioside monosialic acid receptor. Suckling mouse assay was used to assess E. coli stable toxin (ST). As a measure of colonisation, the effect against adherence of E. coli and invasion of E. coli and Shigella flexneri to HEp-2 cells were studied. The decoction had no antibacterial, antiprotozoal, and antiviral activity. It inhibited the production of cholera toxin, and increased the production of labile toxin. Binding of both LT and CT to the GM1 receptor was reduced [68].

\section{Cardiac effect:}

The effect of alcoholic extract of Dalbergia sissoo leaf extract (DSE) (30, 100 and $300 \mathrm{mg} / \mathrm{kg}$ of body weight) was studied in isoproterenol (ISP)-induced myocardial injury in rats. Assessment of myocardial injury was done by estimation of different cardiac injury markers like LDH, CK-MB. Serum cholesterol, LDL, HDL, triglycerides in serum, myocardial infarcted area, oxidative stress and histopathology of heart tissue in rats. Mean arterial pressure and heart rate were recorded in all the groups. Rats pretreated with DSE (30, 100 and $300 \mathrm{mg} / \mathrm{kg}$ of body weight) showed significant $(\mathrm{P}<0.05-0.001)$ improvement in the relative heart weight, myocardial infarcted areas, heart rate and mean arterial pressure in ISP-induced myocardial injury. DSE showed significant $(\mathrm{P}<0.05-0.001)$ improvement in serum LDH, CK-MB, cholesterol, LDL and triglyceride levels at all the dose levels. However, DSE pretreatment had no significant effect on serum HDL level. Pretreatment with DSE $(30,100$ and $300 \mathrm{mg} / \mathrm{kg}$ body weight) showed significant $(\mathrm{P}<0.001)$ reduction in MDA level in 
comparison with myocardial injured rats. Furthermore, antioxidant potential was also improved in terms of improved activities of reduced glutathione, superoxide dismutase and catalase with the DSE pretreatment. Histopathology also showed significant improvement in heart tissue [109].

\section{CNS effects:}

The effect of ethanolic leaf extracts of Dalbergia sissoo (ELDS) on learning and memory activity was evaluated in mice. ELDS was given as 300, 450 and $600 \mathrm{mg} / \mathrm{Kg}$ respectively. The effect of ethanolic leaf extract of Dalbergia sissoo was investigated in mice for memory enhancing activity using various experimental paradigms of learning and memory (Transfer latency (TL) on elevated plus maze and passive avoidance). For memory and learning activity vehicle/ extracts / STD drug administered daily for first seven days, on $8^{\text {th }}$ day dementia was induced by scopolamine. ELDS significantly enhanced the learning and memory activities against the scopolamine induced dementia and significant decrease in acetylcholinesterase level in brain in animals. The memory enhancement activity was due to cholinergic facilitatory effect in animals [110].

The neuroprotective effects of the ethanolic extract of Dalbergia sissoo leaves was evaluated by checking brain weight, antioxidant levels, histopathological and TTC staining studies in cerebral ischemia induced in rats. The ethanolic extracts was given at $300,600 \mathrm{mg} / \mathrm{kg}$ and were compared to negative control (global cerebral ischemic rats). It was observed that prior treatment with Dalbergia sissoo extract $(300 \mathrm{mg} / \mathrm{kg}$ and $600 \mathrm{mg} / \mathrm{kg}$, po for 10days) markedly reversed the brain weight, antioxidant levels and restored to normal levels as compared to ischemia- reperfusion induced oxidative stress groups. Moreover, brain coronal sections staining and histopathological studies revealed protection against ischemic brain damage in the extract treated groups [111]. The neuroprotective effect of ethanolic extract of Dalbergia sissoo leaves was evaluated in 3-nitropropionic acid induced neurotoxic rats. The ethanolic extract of Dalbergia sissoo leaves was administered orally at different doses (300 and $600 \mathrm{mg} / \mathrm{kg}$ ) to neurotoxic rats. During treatment psychopharmacological parameters were recorded, and 24 hours after experiment antioxidant profiles from brain isolates were estimated and histopathology of brain was performed. The ethanolic extract significantly attenuated behavioral alterations, oxidative damage, mitochondrial dysfunction, and striatal/hippocampus damage in 3-nitropropionic acid treated rats [112].

\section{Reproductive effect:}

The anti-spermatogenic efficacy of ethanol extract of stem bark of Dalbergia sissoo was evaluated in healthy fertile men. Semen samples were obtained from 15 healthy fertile men aged 25-35 years. Sperm motility was examined by the Sander-Cramer method. A dose-dependent and time-dependent effect of ethanol extract on sperm motility and sperm viability were observed. Various concentrations affected the motility of sperm. Ethanol extract at a concentration of $20 \mathrm{mg} / \mathrm{ml}$ caused complete immobilization within 3 minutes. Sperm viability and hypo-osmotic swelling was significantly reduced at this concentration. An in vivo antifertility studies were carried out on Swiss male albino mice. Ethanol extract at a dose of $200 \mathrm{mg} / \mathrm{kg}$ body weight resulted in a significant decrease $(\mathrm{P}<0.001)$ in weight of the testis and epididymis. A significant decrease $(\mathrm{P}<$ 0.01 ) in sperm motility and sperm count in the epididymis were observed. Histopathological changes in the epididymis and testis were also recorded [113].

Antifertility effects of Dalbergia sissoo was investigated in male mice. Adult Parkes strain male mice were orally administered aqueous leaf extract of Dalbergia sissoo (50 and $100 \mathrm{mg} / \mathrm{kg}$ body weight/day) for 35 days. Motility, viability and number of spermatozoa in the cauda epididymidis; testis histology; serum level of testosterone; and toxicological effects were evaluated. To assess reversibility, mice were treated with 100 $\mathrm{mg} / \mathrm{kg}$ body weight of Dalbergia sissoo or distilled water for 35 days and sacrificed 56 days later. The fertility parameters were also assessed separately. Histologically, testes of Dalbergia sissoo -treated mice showed dissimilar degenerative changes in the seminiferous tubules. Significant reductions were noted (i) in epididymal sperm motility, viability and number, and (ii) in serum level of testosterone in Dalbergia sissoo -treated mice compared to controls. However, serum levels of alanine aminotransferase, aspartate aminotransferase and creatinine, and haematological parameters were not affected. Libido in Dalbergia sissoo -treated males showed no change, but their fertility was markedly suppressed. By 56 days of treatment withdrawal, the alterations induced in fertility parameters were returned to control levels [114].

\section{Toxicity:}

The acute toxicity study showed that the ethanol bark extract of Dalbergia sissoo was nontoxic up to $3000 \mathrm{mg} / \mathrm{kg}$ body weight in Swiss albino mice [66].Acute toxicity studies were carried out on Wistar rats. Alcohalic bark extracts at dose of 50,100,300,1000, and $3000 \mathrm{mg} / \mathrm{kg}$ body weight were administered after over night fasting. Acute toxicity studies did not reveal any toxic symptoms or death in any of the animal up to the dose level $3000 \mathrm{mg} / \mathrm{kg}$ boy weight [67]. $90 \%$ ethanolic extract was also safe up to $3000 \mathrm{mg} / \mathrm{kg}$, orally in the rats [64]. 
1.5-10g powder and 10-20 g for decoction [58].

\section{DOSE}

\section{CONCLUSION}

The review discussed the chemical constituents, pharmacological effects and therapeutic importance of Dalbergia sissoo as promising herbal drug because of its safety and effectiveness.

\section{REFERENCES:}

[1] Al-Snafi AE. Therapeutic properties of medicinal plants: a review of their effect on reproductive systems (part 1). Ind J of Pharm Sci \& Res 2015; 5(4): 240-248. http://www.ijpsrjournal.com/File_Folder/240248.pdf

[2] Al-Snafi AE. Medicinal plants with antidiabetic effects (part 2): plant based review. IOSR Journal of Pharmacy 2016; 6(7): 49-61. http://www.iosrphr.org/papers/v6i7V2/F06724961.pdf

[3] Al-Snafi AE. Medicinal plants with antioxidant and free radical scavenging effects (part 2): plant based $\begin{array}{llllll}\text { review. } & \text { IOSR } & \text { Journal } & \text { Of }\end{array}$ http://www.iosrphr.org/papers/v6i7V2/G06726282.pdf

[4] Al-Snafi AE. Medicinal plants with antimicrobial activities (part 2): Plant based review. Sch Acad J Pharm 2016; 5(6): 208-239. http://saspublisher.com/wp-content/uploads/2016/07/SAJP-56208-239.pdf

[5] Al-Snafi AE. Medicinal plants with cardiovascular effects (part 2): plant based review. IOSR Journal of Pharmacy 2016; 6(7): 43-62. http://www.iosrphr.org/papers/v6i7V3/E067034362.pdf

[6] Al-Snafi AE. Detoxification capacity and protective effects of medicinal plants (part 2): plant based review. IOSR Journal of Pharmacy http://www.iosrphr.org/papers/v6i7V3/F067036384.pdf

[7] Al-Snafi AE. Beneficial medicinal plants in digestive system disorders (part 2): plant based review. IOSR Journal of Pharmacy 2016; 6(7): 85-92. http://www.iosrphr.org/papers/v6i7V3/G067038592.pdf

[8] Al-Snafi AE. The pharmacology of Equisetum arvense- A review. IOSR Journal of Pharmacy 2017; 7(2): 31-42. http://www.iosrphr.org/papers/v7i2V1/D0702013142.pdf

[9] Al-Snafi AE. Medicinal plants with central nervous effects (part 2): plant based review. IOSR Journal of Pharmacy 2016; 6(8): 52-75. http://www.iosrphr.org/papers/v6i8V1/G068015275.pdf

[10] Al-Snafi AE. Immunological effects of medicinal plants: A review (part 2). Immun Endoc \& Metab Agents in Med Chem 2016; 16(2): 100-121. http://www.eurekaselect.com/146338

[11] Al-Snafi AE. A review on Dodonaea viscosa: A potential medicinal plant. IOSR Journal of Pharmacy 2017; 7(2): 10-21. http://www.iosrphr.org/papers/v7i2V1/B0702011021.pdf

[12] Al-Snafi AE. The pharmacology and medical importance of Dolichos lablab (Lablab purpureus)- A $\begin{array}{llllll}\text { review. IOSR Journal of } & \text { Pharmacy } & \text { 2017; } & \text { 7(2): } & \text {. }\end{array}$ http://www.iosrphr.org/papers/v7i2V1/C0702012230.pdf

[13] Al-Snafi AE. Pharmacological and therapeutic importance of Desmostachya bipinnata- A review. Indo Am J P Sci 2017; 4(01): 60-66. http://iajps.com/pdf/january2017/9.Ali\%20Esmail\%20AlSnafi,IAJPS\%202017,4\%20(01),60-66.pdf

[14] Al-Snafi AE. Chemical constituents and pharmacological effects of Eryngium creticum- A review. Indo Am J P Sci 2017; 4(01): 67-73. http://iajps.com/pdf/january2017/10.\%20Ali\%20Esmail\%20AlSnafi,IAJPS\%202017,\%20(01),\%2067-73.pdf

[15] Al-Snafi AE. The pharmacological and toxicological effects of Coronilla varia and Coronilla scorpioides: A review. The Pharmaceutical and Chemical Journal 2016; 3(2): 105-114. http://tpcj.org/download/vol-3-iss-3-2016/TPCJ2016-03-03-105-114.pdf

[16] Al-Snafi AE. Pharmacological activities of Cotoneaster racemiflorus- A review. The Pharmaceutical and Chemical Journal 2016, 3(2):98-104. http://tpcj.org/download/vol-3-iss-3-2016/TPCJ2016-03-0398-104.pdf

[17] Al-Snafi AE. The constituents and pharmacology of Corchorus aestuans: A review. The Pharmaceutical and Chemical Journal 2016; 3(4):208-214. http://tpcj.org/download/vol-3-iss-4-2016/TPCJ2016-03-04208-214.pdf

[18] Al-Snafi AE. The chemical constituents and pharmacological activities of Cymbopagon schoenanthus: A review. Chemistry Research Journal 2016; 1(5):53-61. http://chemrj.org/download/vol-1-iss-52016/chemrj-2016-01-05-53-61.pdf

[19] Al-Snafi AE. Traditional uses, constituents and pharmacological effects of Cuscuta planiflora. The Pharmaceutical and Chemical Journal 2016; 3(4): 215-219. http://tpcj.org/download/vol-3-iss-42016/TPCJ2016-03-04-215-219.pdf

[20] Al-Snafi AE. Chemical constituents and pharmacological effects of Cynodon dactylon- A review. IOSR Journal of Pharmacy 2016; 6(7): 17-31. http://www.iosrphr.org/papers/v6i7V2/D06721731.pdf 
[21] Al-Snafi AE. A review on Cyperus rotundus A potential medicinal plant. IOSR Journal Of Pharmacy 2016; 6(7): 32-48. http://www.iosrphr.org/papers/v6i7V2/E06723248.pdf

[22] Al-Snafi AE. The pharmacological Importance of Antirrhinum majus - A review. Asian J of Pharm Sci \& Tech 2015; 5(4): 313-320. http://www.ajpst.com/File_Folder/313-320.pdf

[23] Al-Snafi AE. The pharmacological importance of Centaurea cyanus- A review. Int J of Pharm Rev \& Res 2015; 5(4): 379-384. http://www.ijprr.com/File_Folder/379-384.pdf

[24] Al-Snafi AE. The chemical constituents and pharmacological importance of Chrozophora tinctoria. Int J of Pharm Rev \& Res 2015; 5(4): 391-396. http://www.ijprr.com/File_Folder/391-396.pdf

[25] Al-Snafi AE. Chemical constituents and pharmacological importance of Agropyron repens - A review. Research Journal of Pharmacology and Toxicology 2015; 1 (2): 37-41. http://asdpub.com/index.php/rjpt/article/view/244/156

[26] Al-Snafi AE. Chemical constituents and pharmacological effects of Citrullus colocynthis - A review. IOSR Journal of Pharmacy 2016; 6(3): 57-67. http://www.iosrphr.org/papers/v6i3/F0635767.pdf

[27] Al-Snafi AE. Medical importance of Cichorium intybus - A review . IOSR Journal of Pharmacy 2016; 6(3): 41-56. http://www.iosrphr.org/papers/v6i3/E0634156.pdf

[28] Al-Snafi AE. Pharmacological importance of Clitoria ternatea - A review. IOSR Journal of Pharmacy 2016; 6(3): 68-83. http://www.iosrphr.org/papers/v6i3/G0636883.pdf

[29] Al-Snafi AE. The medical Importance of Cicer arietinum - A review. IOSR Journal of Pharmacy 2016; 6(3): 29-40. http://www.iosrphr.org/papers/v6i3/D0632940.pdf

[30] Al-Snafi AE. Medical importance of Anthemis nobilis ( Chamaemelum nobilis)- A review. Asian Journal of Pharmaceutical Science \& Technology 2016; 6(2): 89-95. http://www.ajpst.com/File_Folder/8995(ajpst).pdf

[31] Al-Snafi AE. Adonis aestivalis: pharmacological and toxicological activities- A revew. Asian Journal of Pharmaceutical Science \& Technology 2016; 6(2): 96-102. http://www.ajpst.com/File_Folder/96102(ajpst).pdf

[32] Al-Snafi AE. The pharmacological activities of Cuminum cyminum - A review. IOSR Journal of Pharmacy 2016; 6(6): 46-65. http://www.iosrphr.org/papers/v6i6V2/G066024665.pdf

[33] Al-Snafi AE. Medical importance of Cupressus sempervirens- A review. IOSR Journal of Pharmacy 2016; 6(6): 66-76. http://www.iosrphr.org/papers/v6i6V2/H066026676.pdf

[34] Al-Snafi AE. The contents and pharmacology of Crotalaria juncea- A review. IOSR Journal of Pharmacy 2016; 6(6): 77-86. http://www.iosrphr.org/papers/v6i6V2/I066027786.pdf

[35] Al-Snafi AE. The medical importance of Cydonia oblonga- A review. IOSR Journal of Pharmacy 2016; 6(6): 87-99. http://www.iosrphr.org/papers/v6i6V2/J066028799.pdf

[36] Al-Snafi AE. The pharmacology of Crocus sativus- A review. IOSR Journal of Pharmacy 2016; 6(6): 838. http://www.iosrphr.org/papers/v6i6V3/C06630838.pdf

[37] Al-Snafi AE. The chemical constituents and therapeutic importance of Cressa cretica- A review. IOSR Journal of Pharmacy 2016; 6(6): 39-46. http://www.iosrphr.org/papers/v6i6V3/D06633946.pdf

[38] Al-Snafi AE. The Pharmacological and therapeutic importance of Cordia myxa- A review. IOSR Journal of Pharmacy 2016; 6(6): 47-57. http://www.iosrphr.org/papers/v6i6V3/E06634757.pdf

[39] Al-Snafi AE. The contents and pharmacological importance of Corchorus capsularis- A review. IOSR Journal of Pharmacy 2016; 6(6): 58-63. http://www.iosrphr.org/papers/v6i6V3/F06635863.pdf

[40] Al-Snafi AE. The chemical constituents and pharmacological effects of Convolvulus arvensis and Convolvulus scammonia- A review. IOSR Journal of Pharmacy 2016; 6(6): 64-75. http://www.iosrphr.org/papers/v6i6V3/G06636475.pdf

[41] Al-Snafi AE. A review on chemical constituents and pharmacological activities of Coriandrum sativum. IOSR Journal of Pharmacy 2016; 6(7): 17-42. http://www.iosrphr.org/papers/v6i7V3/D067031742.pdf

[42] Al-Snafi AE. Pharmacology and toxicology of Conium maculatum- A review. The Pharmaceutical and Chemical Journal 2016; 3(2):136-142. http://tpcj.org/download/vol-3-iss-2-2016/TPCJ2016-03-02-136142.pdf

[43] Al-Snafi AE. The constituents and pharmacology of Cnicus benedictus- A review. The Pharmaceutical and Chemical Journal 2016; 3(2):129-135. http://tpcj.org/download/vol-3-iss-2-2016/TPCJ2016-03-02129-135.pdf

[44] Al-Snafi AE. Medicinal importance of Colchicum candidum- A review. The Pharmaceutical and Chemical Journal 2016; 3(2):111-117. http://tpcj.org/download/vol-3-iss-2-2016/TPCJ2016-03-02-111117.pdf

[45] Al-Snafi AE. Nutritional value and pharmacological importance of citrus species grown in Iraq. IOSR Journal of Pharmacy 2016; 6(8): 76-108. http://www.iosrphr.org/papers/v6i8V1/H0680176108.pdf

[46] Al-Snafi AE. Pharmacological activities of Cotoneaster racemiflorus- A review. The Pharmaceutical and Chemical Journal 2016, 3(2):98-104. 
[47] Al-Snafi AE. The pharmacological and toxicological effects of Coronilla varia and Coronilla scorpioides: A Review. The Pharmaceutical and Chemical Journal 2016, 3(2):105-114.

[48] Al-Snafi AE. The constituents and pharmacology of Corchorus aestuans: A review. The Pharmaceutical and Chemical Journal 2016; 3(4):208-214.

[49] Al-Snafi AE. The chemical constituents and pharmacological activities of Cymbopagon schoenanthus: A review. Chemistry Research Journal 2016; 1(5):53-61.

[50] Al-Snafi AE. Traditional uses, constituents and pharmacological effects of Cuscuta planiflora . The Pharmaceutical and Chemical Journal 2016; 3(4): 215-219.

[51] Bharath M, Tulasi ELR, Sudhakar K and Eswaraiah MC. Dalbergia sissoo DC - An important medicinal plant. IJRPC 2013; 3(2): 384-388.

[52] Mukerjee SK, Saroja T, Seshadri TR. Dalbergichromene: A new neoflavonoid from stem- bark and heartwood of Dalbergia sissoo, Tetrahedron 1971; 27(4):799-803.

[53] Vasudeva N, Vats M, Sharma SK and Sardana S. Chemistry and biological activities of the genus Dalbergia - A review. Pharmacognosy Reviews 2009; 3(6):307-319.

[54] Mohammad A and Kumar A. Phytochemical investigation and evaluation of antinociceptive activity of ethanolic extract of Dalbergia sissoo (Roxb.) bark, 2011; 2(1):76-79.

[55] Bhattacharya M, Singh A and Ramrakhyani C. Dalbergia sissoo-variability in morphology. Journal of Medicinal Plants Studies 2014; 2(3): 8-13.

[56] Sheikh MI. A quick guide to useful nitrogen fixing trees from around the world, NFT Highlights, NFTA 1989: 89:07.

[57] Orwa C, Mutua A, Kindt R , Jamnadass R and Anthony s. Agroforestree Database: a tree reference and selection guide version 4.0, 2009, http://www. worldagroforestry .org/ sites/treedbs/treedatabases.asp

[58] Khare CP. Indian medicinal plants: an illustrated dictionary. Springer-Verlag, New York, USA, 2007: 199-201.

[59] Ramrakhiyani C, Gaur VN and Athaley R. Comparative and therapeutic studies Of some medicinal plants of family fabaceae. IOSR Journal of Pharmacy and Biological Sciences 2016; 11(2): 17-19.

[60] Nadkarni KM. Indian Materia Medica. $3^{\text {rd }}$ ed. Bombay: Popular Book 1954:432.

[61] Ghani A. Medicinal plants of Bangladesh: chemical constituents and uses. $1^{\text {st }}$ ed. Asiatic Society of Bangladesh 1998: 155-156.

[62] Rashida GJN, Venkatarathnakumar T, Aruna AD, Gowri R, Parameshwari R, Shanthi M and Raadhika K. Pharmacognostic and preliminary phytochemical evaluation of the leaves of Dalbergia sissoo Roxb. Asian J Pharm Clin Res 2012; 5(3): 115-119.

[63] Kamal H. Shaltout and Keshta AE. The biology of Egyptian woody perennials 4. Dalbergia sissoo Roxb. ex DC. Ass Univ Bull Environ Res 2011; 14(2): 131-153.

[64] Asif M and Kumar A, Anti-Inflammatory activity of ethanolic Extract of Dalbergia sissoo (Roxb.) bark, Malaysian Journal of Pharmaceutical Sciences 2009; 7(10): 39-50.

[65] Gnanaraja R, Prakash V, Peter S and Mahendraverman M. Qualitative and quantitative phytochemicals analysis of selected fabaceae medicinal plants from Allahabad region. The Pharma Innovation Journal 2014; 3(7): 53-56.

[66] Asif $M$ and Kumar A. Phytochemical investigation and evaluation of antinociceptive activity of ethanolic extract of Dalbergia sissoo (Roxb.) bark. Journal of Natural Science, Biology and Medicine 2011; 2: 76-79.

[67] Ul-Islam $M$ and Elhddad S. Phytochemical investigation and evaluation of analgesic activity of ethonolic extract of Dalbergia sissoo (Roxb.) bark. J Nat Prod Plant Resour 2012; 2 (6):701-704.

[68] Brijesh S, Daswani PG, Tetali P, Antia NH and Birdi TJ. Studies on Dalbergia sissoo (Roxb.) leaves: Possible mechanism(s) of action in infectious diarrhea. Indian Journal of Pharmacology 2006; 38, 120 124.

[69] Aly IM, El-Sayed AB, Gohar YM and Salem MZM. The value-added uses of Ficus retusa and Dalbergia sissoo grown in Egypt: GC/MS analysis of extracts. J Forest \& Industries 2013; 2(3): 34-41.

[70] Behera PC, Verma SM, Kumar PM, Das NB, Mishra PM and Baliarsingh S. Anti-inflammatory and anti-microbial activity of chalcone from Dalbergia sissoo Roxb leaves. American Journal of Phytomedicine and Clinical Therapeutics 2013;1(2): 186-194.

[71] Rana V, Das MK, Gogoi S and Kumar V. Multifunctional properties of polysaccharides from Dalbergia sissoo, Tectona grandis and Mimosa diplotricha. Carbohydr Polym 2014;102: 341-350.

[72] Rana V, Kumar V and Soni PL. Structural characterization of an acidic polysaccharide from Dalbergia sissoo Roxb. leaves. Carbohydr Polym 2012; 90(1): 243-250.

[73] Kumar V, Rana V and Soni PL. Molecular weight determination and correlation analysis of Dalbergia sissoo polysaccharide with constituent oligosaccharides. Phytochem Anal 2013; 24(1): 75-80. 
[74] Farag SF, Ahmed AS, Terashima K, Takaya Y and Niwa M. Isoflavonoid glycosides from Dalbergia sissoo. Phytochemistry 2001; 57(8): 1263-1268.

[75] Dixit P, Chillara R, Khedgikar V, Gautam J, Kushwaha P, Kumar A, Singh D, Trivedi R and Maurya R. Constituents of Dalbergia sissoo Roxb. leaves with osteogenic activity. Bioorg Med Chem Lett 2012; 22(2):890-897.

[76] Mukerjee SK, Saroja T, Seshadri TR. Dalbergichromene: A new neoflavonoid from stem- bark and heartwood of Dalbergia sissoo, Tetrahedron 1971; 27(4):799-803.

[77] Sharma A, Chibber SC and Chawla H M. Caviunin 7-O-gentiobioside from Dalbergia sissoo pods. Phytochemistry 1979; 18: 1253.

[78] Sarg T, Ateya A, Abdel-Ghani A, Badr W and Shams G. Phytochemical and pharmacological studies of Dalbergia sissoo growing in Egypt. Journal of Pharmaceutical Biology 1999; 37 (1): 54-62.

[79] Kaur A, Sing S, Priyanka C, avatar K and Singh MP. Evaluation of antioxidant potential of stem bark extract of Dalbergia sissoo. Journal of Pharmacy Research 2011; 4(10): 3439-3441.

[80] Kumari A and Kakkar P. Screening of antioxidant potential of selected barks of Indian medicinal plants by multiple in vitro assays. Biomedical and Environmental Sciences 2008; 21: 24-29.

[81] Hood MM, Tembhurne SV and Sakarkar DM. Anthelmintic activity of different extracts of Dalbergia sissoo Roxb on Indian adult earthworms. Der Pharma Chemica 2011; 3: 142-146.

[82] Kumar UN. Evaluation of anthelmintic activity of Dalbergia sissoo roxb. International Journal of Pharmaceuticl Science and Research 2011; 2(1):171-174.

[83] Singh NK, Jyoti, Vemu B, Prerna M, Singh H, Dumka VK and Sharma SK. Acaricidal activity of leaf extracts of Dalbergia sissoo Roxb. (Fabaceae) against synthetic pyrethroid resistant Rhipicephalus (Boophilus) microplus. Res Vet Sci 2016;106:1-6.

[84] Adenusi AA and Odaibo AB. Effects of varying concentrations of the crude aqueous and ethanolic extracts of Dalbergia sissoo plant parts on Biomphalaria Pfeifferi egg masses. Afr J Tradit Complement Altern Med 2009; 6(2): 139-149.

[85] Ansari MA, Razdan RK, Tandon M and Vasudevan P. Larvicidal and repellent actions of Dalbergia sissoo Roxb. (F. Leguminosae) oil against mosquitoes. Bioresource Technology 2000; 73: 207-211.

[86] Sidana JK, Saini V and Dahiya S. Analgesic and anti-inflammatory activities of Dalbergia sissoo leaves extract. International Journal of Natural Product Science 2012; (Spl issue 1): 134.

[87] Hugar M.H, Hosamani K.M and Ahmed L. Phytochemical and pharmacological studies of ethanol extract of Dalbergia sissoo seeds. An approach for the in vivo analgesic and antipyretic activities. International Journal of Pharma and Bio Sciences 2010; 1(4): 272-280.

[88] Hajare SW, Chandra S, Tandan SK, Sarma J, Lal J and Telang AG. Analgesic and antipyretic activities of Dalbergia sissoo leaves. Indian Journal of Pharmacology 2000; 32: 357-360.

[89] Hajare SW, Chandra S, Sharma J, Tandan SK, Lal J and Telang AG. Anti-inflammatory activity of Dalbergia sissoo leaves. Fitoterapia 2001; 72: 131-139.

[90] Panda SK, Padhy RP, Pani S and Bal K. Phytochemical investigation and antidiabetic activity of leaf extracts of Dalbergia sissoo (Roxb.) in alloxan induced diabetic rats. Science and Medical Res 2016; 1(2): 186-189.

[91] Niranjan PS, Singh D, Prajapati K and Jain SK. Antidiabetic activity of ethanolic extract of Dalbergia sissoo L. leaves in alloxan-induced diabetic rats. International Journal of Current Pharmaceutical Research 2010; 2: 24-27.

[92] Saini S and Sarma S. Antidiabetic activity of different extracts of Dalbergia sissoo DC. stem bark on streptozotocin-nicotinamide induced type 2 diabetic rats. Int J Pharm Pharm Sci 2013; 5(4): 228-235.

[93] Pund KV, Vyawahare NS, Gadakh RT and Murkute VK. Antidiabetic Evaluation of Dalbergia sissoo against alloxan induced diabetes mellitus in wistar albino rats. J Nat Prod Plant Resour 2012; 2 (1): 81 88.

[94] Lakshmi TM, Radha R, Jayshree N. In vitro hyperpigmentant activity on the bark of Dalbergia sissoo Roxb. American Journal of Pharmacy \& Health Research 2014; 2(3): 93-98.

[95] Gautam J, Kumar P, Kushwaha P, Khedgikar V, Choudhary D, Singh D, Maurya R and Trivedi R. Neoflavonoid dalbergiphenol from heartwood of Dalbergia sissoo acts as bone savior in an estrogen withdrawal model for osteoporosis. Menopause 2015; 22(11):1246-1255.

[96] Khedgikar V, Gautam J, Kushwaha P, Kumar A, Nagar GK, Dixit P, Chillara R, Voruganti S, Singh SP, Uddin W, Jain GK, Singh D, Maurya R,Chattopadhyay N and Trivedi R. A standardized phytopreparation from an Indian medicinal plant (Dalbergia sissoo) has antiresorptive and bone-forming effects on a postmenopausal osteoporosis model of rat. Menopause 2012;19(12):1336-1346.

[97] Kushwaha P, Khedgikar V, Gautam J, Dixit P, Chillara R, Verma A, Thakur R, Mishra DP, Singh D, Maurya R, Chattopadhyay N, Mishra PR, Trivedi R. A novel therapeutic approach with caviunin- 
based isoflavonoid that en routes bone marrow cells to bone formation via BMP2/Wnt- $\beta$-catenin signaling. Cell Death Dis 2014; 5: e1422.

[98] Yadav H, Yadav M, Jain S, Bhardwaj A, Singh V, Parkash O and Marotta F. Antimicrobial property of a herbal preparation containing Dalbergia sissoo and Datura tramonium with cow urine against pathogenic bacteria. Int J Immunopathol Pharmacol 2008; 21(4):1013-1020.

[99] Hussain M, Ullah Khan MR, Raza SM, Aziz A, Bakhsh H and Majeed A. Assessment of the antimicrobial potential of Dalbergia sisso against eight pathogenic bacteria - an in vitro study. International Journal of Pharma Sciences 2014; 4(5): 702-706.

[100] Lakshmi TM, Radha R and Jayshree N. In vitro antioxidant activity, total penolic and total flavanoid content in extracts from the bark of Dalbergia sissoo Roxb. IJPSR 2014; 5(5): 226-231.

[101] Roy N, Laskar R, Ismail SK and Bequm NA. A detailed study on the antioxidant activity of the stem bark of Dalbergia sissoo Roxb., an Indian medicinal plant. Food Chemistry 2011; 126(3):1115-1121.

[102] Pooja PS, Samanta KC and Vikas G, Pharmacophore evaluation of nitric oxide and hydrogen peroxide scavenging activity of Dalbergia sissoo roots. Pharmacophore 2010; 1(2): 77-81.

[103] An RB, Jeong GS and Kim YC. Flavonoids from the heartwood of Dalbergia odorifera and their protective effect on glutamate-induced oxidative injury in HT22 cells. Chemical \& Pharmaceutical Bulletin 2008; 56: 1722-1724.

[104] Khan MI and Khan MR. Gastroprotective potential of Dalbergia sissoo Roxb. stem bark against diclofenac-induced gastric damage in rats. Osong Public Health Res Perspect 2013; 4(5): 271-277.

[105] Baral SR, Acharya SR, Parajuli DR, Swamy S and Gyawali R. Antiulcer activity of ethanolic bark extract of Dalbergia sissoo on experimental ulcer models. Int J of Allied Med Sci and Clin Research 2016; 4(1): 52-60.

[106] Kalaskar MG, Divekar VB, Chaugule PD, Surana SJ and Baheti DG. Studies on anti-diarrheal activity of Dalberjia sissoo Roxb. in experimental animals. Pharmacologyonline 2010; 1: 453-457.

[107] Mujumdar AM, Misar AV and Upadhye AS. Antidiarrhoeal activity of ethanol extract of the bark of Dalbergia lanceolaria. Journal of Ethnopharmacology 2005; 102: 213-216.

[108] Chandra P, Sachan N and Pal D. Protective effect of Dalbergia sissoo Roxb. ex DC. (family: Fabaceae) leaves against experimentally induced diarrhoea and peristalsis in mice. Toxicol Ind Health 2015; 31(12): 1229-1235.

[109] Kasa JK, Singh TU, Parida S, Addison MP, Darzi SA, Choudhury S, Kandasamy K, Singh V, Dash JR, Shanker K and Mishra SK. Assessment of Indian rosewood (Dalbergia sissoo) standardized leaf extract on isoproterenol-induced myocardial injury in rats. Cardiovasc Toxicol 2015;15(3):250-260.

[110] Sau S and Handral M. Evaluation of memory enhancing activity of leaf extract of Dalbergia sissoo in mice. International Journal of Pharmaceutical Sciences and Drug Research 2015; 7(3): 263-269.

[111] Swaroop TVSS, Handral M, Mitul P. Neuroprotection evaluation of Dalbergia sissoo Roxb. leaves against cerebral ischemia/ reperfusion (I/R) induced oxidative stress in rats. IAJPR 2013; 3(5): 36893701.

[112] Swaroop TVSS, Banerjee S and Handral M. Neuroprotective evaluation of leaf extract of Dalbergia sissoo in 3-Nitropropionic acid induced neurotoxicity in rats. Int J of Pharmac Sci and Drug Res 2014; 6(1): 41-47.

[113] Vasudeva N and Vats M. Anti-spermatogenic activity of ethanol extract of Dalbergia sissoo Roxb. stem bark. Journal of Acupuncture and Meridian Studies 2011; 4: 116-122.

[114] Verma HP and Singh SK. Effect of aqueous leaf extract of Dalbergia sissoo Roxb. on spermatogenesis and fertility in male mice. Eur J Contracept Reprod Health Care 2014; 19(6):475-486. 